\title{
Molnár-Kovács Zsófia
}

kovacs.zsofia@pte.hu

PTE Bölcsészet- és Társadalomtudományi Kar Neveléstudományi Intézet, Nevelés- és Müvelődéstörténeti Tanszék

Online lehetöségek a történeti tankönyvkutatások forrásainak feltárásában

\section{Bevezetés}

A tananyag kiemelten azon online hazai adatbázisokat és forráscsoportokat helyezi az érdeklődés fókuszába, melyek a történeti tankönyvkutatások során — a közgyüjteményekben elérhető forrásanyagokon felül - elektronikus módon lehetővé teszik a kapcsolódó elsődleges és másodlagos források keresését, megtekintését, (esetleg) kutatási célú letöltését. Az áttekintett adatbázisok sorában kiemelkedik az Arcanum Digitális Tudománytár ${ }^{1}$, valamint a Hungaricana közgyüjteményi portál. ${ }^{2}$ Ez utóbbi adatbázis két gyüjteménye mindenképpen hangsúlyos: a Magyarországi Rendeletek Tára ${ }^{3}$ és az Iskolai értesitók ${ }^{4} \mathrm{~A}$ tananyagban kifejtett online lehetőségek kibontását a dualizmus kori források példáján keresztül szemléltetjük.

\section{Kutatási előzmények}

A történeti tankönyvkutatások magyar nyelvü forrásainak feltárását, azok hozzáférési lehetőségeinek kibontását a 2010-es években szisztematikusan, fokról fokra építettük, a hangsúlyok horizontálisan és vertikálisan is formálódtak, illetve mélyültek. E folyamat első jelentősebb állomásának „,A tankönyvkutatás magyar bibliográfiája (2000-2010)” címü forrásmunka-jegyzéket tekintjük a közzétett 1077 bibliográfiai tétellel (lásd Molnár-Kovács, 2013b; lásd még Márhoffer, 2013).

- Az internetes hivatkozások letöltési és ellenőrzési dátuma 2021. január 30.

1 Arcanum Digitális Tudománytár - https://adtplus.arcanum.hu/hu/

2 Hungaricana közgyüjteményi portál - https://library.hungaricana.hu/hu/

3 Magyarországi Rendeletek Tára 1867-1945

https://library.hungaricana.hu/hu/collection/ogyk_rendeletek_tara/

4 Iskolai értesítők - Hungaricana

https://library.hungaricana.hu/hu/collection/iskolai_ertesitok 
„A kötet összeállitásának célja egy olyan, teljességre törekvő irodalomjegyzék elkészitése volt, mely egyrészt számba veszi a tankönyvi kérdéskör általános perspektíváit, a tankönyvkutatás pozícióit, tendenciáit elötérbe helyezö bibliográfiai tételeket (lásd a Tankönyvekröl általában - szakirodalmi alapok c. elsö fejezet), másrészt pedig demonstrálja a történelemtankönyvek kutatásának súlypontjait, a történelem-tankönyvi megközelitésmódokat és reprezentációkat (lásd a Történelemtankönyvkutatás c. második fejezet). " (Molnár-Kovács, 2013a)

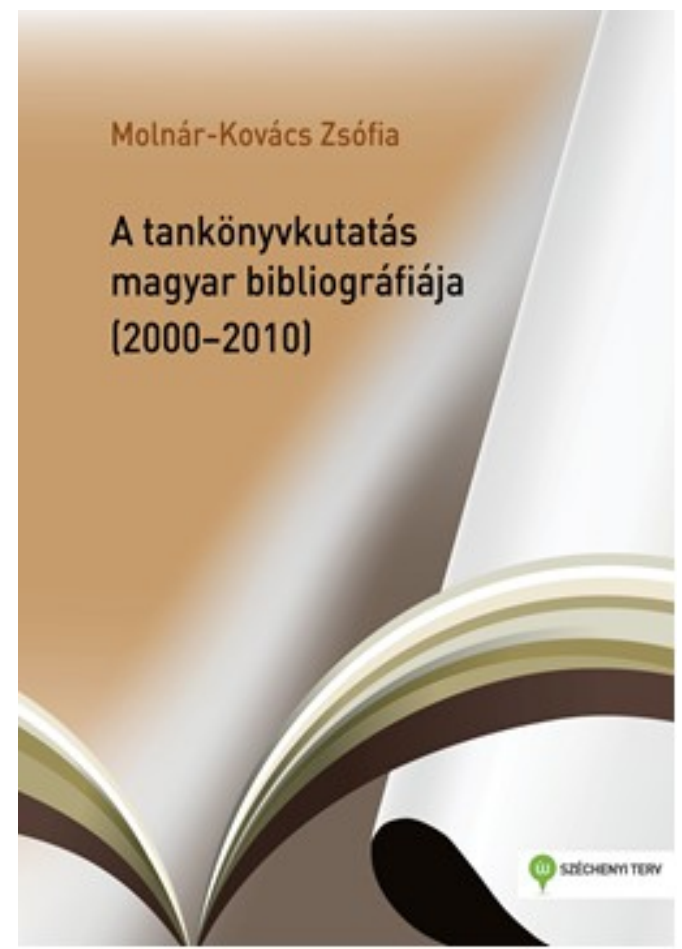

1. kép: A tankönyvkutatás magyar bibliográfiája (2000-2010) (Molnár-Kovács, 2013b) - https://bit.ly/3rQJ2p0

2017-ben jelent meg „A tankönyvkutatások dualizmus kori forrásai” címü kötet, mely — az 1867 és 1918 közötti időszak tankönyvkutatásának forrásismereti aspektusait tárgyaló bevezető tanulmány, valamint a források főbb hazai és nemzetközi lelöhelyére, helyszínére ${ }^{5}$ fókuszáló írással párhuzamosan — a forrásközlésre helyezi a hangsúlyt.

5 Országos Pedagógiai Könyvtár és Múzeum, Budapest https://www.opkm.hu

Georg-Eckert-Institut - Leibniz-Institut für internationale Schulbuchforschung, Braunschweig - http://www.gei.de/ 
„A könyv legterjedelmesebb és legmeghatározóbb része a $78 \mathrm{db}$ forrást, illetve forrásrészletet felvonultató „,Forrásgyüjtemény”, melynek elkészitése során több szempont is érvényesült. A gyüjteményben elsödleges és másodlagos írásos források kaptak helyet [...]. A források kiválasztása során sokrétü, gazdag válogatást tükrözö forrásbázis létrehozására törekedtünk, mely változatos képet ad a korszakkal kapcsolatos tankönyvkutatások lehetséges írásos kútföiröl." (Molnár-Kovács, 2017. 15-16. o.) „A könyv harmadik és egyben utolsó nagyobb egysége „A dualizmus kori tankönyvek kutatásának 1918 utáni annotált hazai szakirodalma”. A jegyzék összesen 81 tételt tartalmaz, köztük az OPKM '80-as években megjelent tankönyvi kötetkatalógusait, szaktanulmányokat, PhD értekezéseket és számos folyóiratcikket." (Molnár-Kovács, 2017. 20. o.)

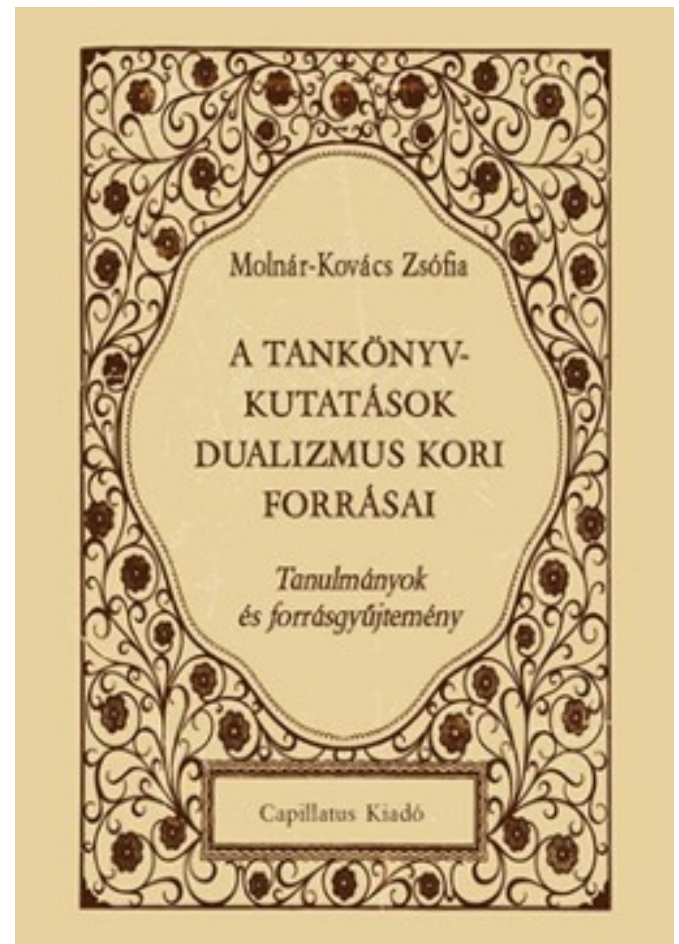

2. kép: A tankönyvkutatások dualizmus kori forrásai (Molnár-Kovács, 2017)

Két évvel később, 2019-ben látott napvilágot „A magyar tankönyvkutatások forrásdimenziói (1867-1918)" címü munka, mely a fellelhető források tipizálását helyezi fókuszba, s a megalkotott forrásdimenziókban (aldimenziókban) rejlő forráselemző lehetőségeket kiemelten tárgyalja. 
„E könyv tehát A tankönyvkutatások dualizmus kori forrásai címü kötetben megkezdett törekvéseket viszi tovább, s az abban elhelyezett írásos forrásokkal, forráscsoportokkal, forrásismereti háttérrel foglalkozik behatóbban. Ahogy jelen könyv címében is szerepel, ún. forrásdimenziók felállitásával, azokhoz rendelve kivántuk strukturálni azon forrásokat, melyek mentén a dualizmus kori tankönyvek kutatása eredményesen megvalósitható. E forrásdimenziók - melyek egyúttal a könyv fö szerkezeti csomópontjait is képezik - a következök: oktatáspolitikai dimenzió, pedagógiai-iskolai dimenzió, szakmai irodalom dimenziója." (Molnár-Kovács, 2019. 14. o.)

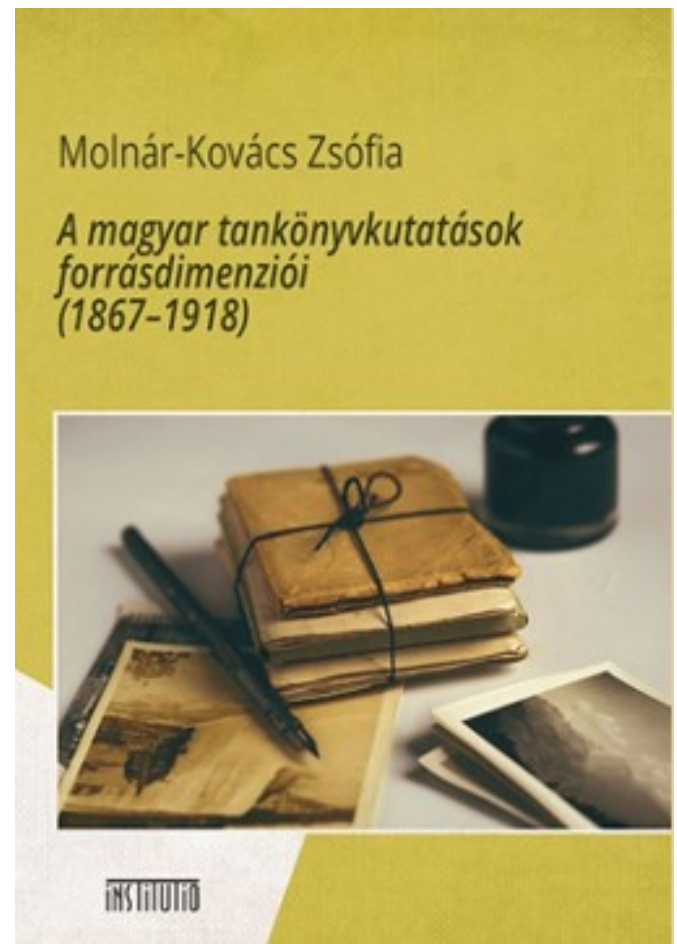

3. kép: A magyar tankönyvkutatások forrásdimenziói (1867-1918) (Molnár-Kovács, 2019)

Vajda Barnabás 2020-ban megjelent munkájában mindhárom kötetet (Molnár-Kovács, 2013b, 2017, 2019) egy önálló alfejezetben tárgyalja, azok forrásfeltáró, további tankönyvkutatásokat ösztönző érdemeire fel is hívja olvasói figyelmét (lásd Vajda, 2020. 45-48. o.). Vajda Barnabás „Történelemdidaktika és történelemtankönyv-kutatás” címü könyvének szerzői előszavában megfogalmazott bevezető gondolatok pedig a szakirodalmi források tankönyvkutatásokban betöltött szerepét és relevanciáját (is) hangsúlyozzák. 
„Nagyon fontos, hogy a tankönyvkutatásnak mindig a szaktudomány legújabb ismeretein kell állnia, arra kell támaszkodnia, abból kell kiindulnia. A tankönyvkutatónak ismernie kell a vizsgált téma legrelevánsabb szakirodalmát, lehetöleg a nemzetközit is. " (Vajda, 2020. 11. o.)

\section{A magyar tankönyvkutatás forrásdimenziói}

A tananyag fő sodrában, illetve a továbbiakban a magyar tankönyvkutatások mindhárom említett forrásdimenziójára (oktatáspolitikai dimenzió, pedagógiai-iskolai dimenzió, szakmai irodalom dimenziója) vetünk egy pillantást, hogy lássuk, mely források, forráscsoportok digitális hozzáférésére van lehetőség, illetve azok mely hazai adatbázis révén és milyen módon hozzáférhetőek. A három dimenzióhoz tartozó aldimenziók áttekintési sorrendjét a 4. kép is szemlélteti, melynek segítségével az egyes dimenziók/aldimenziók rendszeréről is világos képet kapunk.

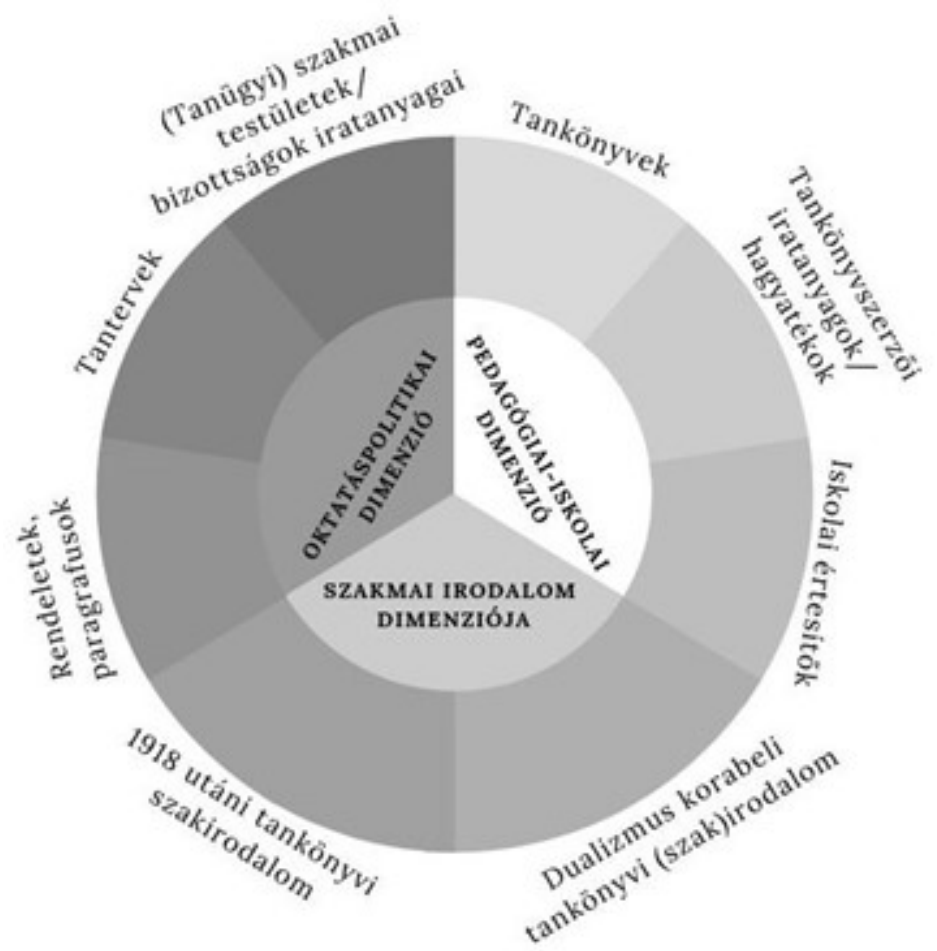

4. kép: A magyar tankönyvkutatások forrásdimenziói (1867-1918) (Forrás: Molnár-Kovács, 2019. 15. o.) 


\title{
Hazai online adatbázisok történeti tankönyvkutatásokat segítő digitális tartalmai
}

\author{
Rendeletek, paragrafusok
}

Az 1867-1918 közötti időszak hazai rendeleteinek főbb forráskiadványai: a Magyarországi Rendeletek Tára, a Néptanitók Lapja, a Hivatalos Közlöny (valamint „A magyarországi népoktatásügy, kereskedelmi és ipari szakoktatás szervezete és közigazgatása" címü kötetek, lásd Lévay, Morlin és Szuppán, 1893; Morlin és Szuppán, 1898).

E forráskiadványok föbb online lelőhelyei: a Hungaricana közgyüjteményi portál ${ }^{6}$, továbbá az Arcanum Digitális Tudománytár. ${ }^{7}$ Emellett vethetünk egy pillantást a Digitalizált Törvényhozási Tudástárra ${ }^{8}$ is, mely a fókuszba helyezett rendeletek kapcsán szintén a Hungaricanara irányítja át az érdeklődőket.

Ahogy a Digitalizált Törvényhozási Tudástár a Magyarországi Rendelete Tárával ${ }^{9}$ kapcsolatban hangsúlyozza: „Az adatbázis az 1867 és 1945 között megjelentetett kiadvány nyomtatott köteteinek digitalizált változatát tartalmazza. [...] A Rendeletek Tára válogatva tartalmazza az adott időszakban kiadott királyi (kormányzói) rendeleteket, miniszterelnöki rendeleteket, kormány- [...] rendeleteket, miniszteri rendeleteket, egyéb, a jogszabályok körébe nem tartozó rendelkezéseket”. ${ }^{10} \mathrm{Az}$ Arcanum Digitális Tudománytár pedig „,a teljesség igényével teszi hozzáférhetôvé és kereshetövé múltunk legfontosabb nyomtatott forrásait (tudományos és szakfolyóiratok, heti- és napilapok, valamint lexikonok és tematikus könyvgyüjtemények legjavát). [...] A teljes szövegü keresés új távlatokat nyit az érdeklödök számára, a dokumentumok minden szava, kifejezése, személy és helységnevek könnyen, gyorsan kutathatók, a kutatónak így már csak a források értékelését, a következtetések levonását kell elvégeznie." 11

${ }^{6}$ Hungaricana közgyüjteményi portál - https://library.hungaricana.hu/hu/

7 Arcanum Digitális Tudománytár - https://adtplus.arcanum.hu/hu/

8 „A Digitalizált Törvényhozási Tudástárban megtalálható dokumentumok gerincét alkotják az ún. jogforrások. A portálon a felhasználók átfogó tájékoztatást kaphatnak a magyar jogforrási rendszer múltjáról, és az írott jogforrások rendszeréről.,, Digitalizált Törvényhozási Tudástár - Gyüjteményismertetők https://dt.ogyk.hu/hu/

9 Magyarországi Rendeletek Tára 1867-1945 https://library.hungaricana.hu/hu/collection/ogyk_rendeletek_tara/

10 Digitalizált Törvényhozási Tudástár - Magyarországi Rendeletek Tára https://dtt.ogyk.hu/hu/gyujtemenyismertetok/jogforrasok/rendeletektara/item/404-magyarorszagi-rendeletek-tara

11 Arcanum Digitális Tudománytár - Ismertető - http://www.arcanum.hu/hu/adt/ 


\section{Tantervek}

A dualizmus korabeli tantervek online hozzáférési lehetőségéröl ugyan nincsen tudomásunk, azonban a Pécsi Tudományegyetem Egyetemi Könyvtár és Tudásközpont digitalizált dokumentumgyüj-

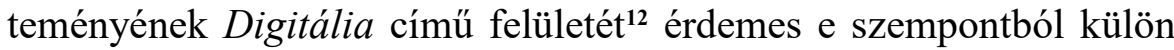
is górcső alá venni. A Digitálián kiemelten a két világháború közötti időszakban jóváhagyott tantervekből és utasításokból ${ }^{13}$ szemezgethetünk, azonban a digitális források körének bővítése az olvasói igények felmérésével párhuzamosan folyamatos. Így e törekvések mentén a továbbiakban a tantervi források szélesebb körü áttekintésére is lehetőség adódhat.

\section{(Tanügyi) szakmai testületek, bizottságok iratanyaga}

A dualizmus korát tekintve kiemelt figyelmet szenteltünk a korabeli (tanügyi) szakmai testületek utókor számára fennmaradt írásos dokumentációjára, ezen belül pedig többek között a tankönyvbizottsági értekezlet (1868. augusztus 3-11.) jegyzőkönyvére (lásd MolnárKovács, 2019. 52-58. o.; lásd még Molnár-Kovács, 2017).

A bizottsági ülés jegyzőkönyve több forrásból is ismert, illetve több korabeli dokumentumban is megjelent. Hozzáférhető a Néptanítók Lapjában, a Budapesti Közlönyben, továbbá Dölle Ödön 1871ben kiadott munkájában, „A nevelészet történeté”-ben (A népiskolai olvasó-, tan-és vezérkönyvek kidolgozása..., 1868a, 1868b, 1868c, 1868d; Dölle, 1871. 261-285. o.). Emellett pedig Molnár-Kovács Zsófia 2017. évi forrásgyüjteményében is olvasható (lásd MolnárKovács, 2017. 183-208. o.). A megjelölt forráskiadványok (Dölle, 1871 kivételével) föbb online lelöhelye az Arcanum Digitális Tudománytár ${ }^{14}$, ahol a megjelölt folyóiratok hasábjain a jegyzőkönyv szövege teljes terjedelmében megtalálható.

\section{Tankönyvek}

Azt bátran kijelenthetjük, hogy egy adott korszak tankönyveinek többszempontú vizsgálata természetesen elsősorban maguknak a tankönyvi köteteknek a kézbevétele, alapos áttekintése, részletes elemzése révén lehetséges. A magyar tankönyvek 1867-1918 közötti idö-

12 Digitália - Pécsi Tudományegyetem - https://digitalia.lib.pte.hu

13 Tantervek - Digitália - Pécsi Tudományegyetem - https://bit.ly/3t77gwT

14 Arcanum Digitális Tudománytár - https://adtplus.arcanum.hu/hu/ 
szakból ránk maradt példányainak kutatói szándékú kézbevételére napjainkban a legkiemelkedőbb hazai tankönyvállománnyal rendelkező intézményben, az Országos Pedagógiai Könyvtár és Múzeumban, illetve annak könyvtárában, Nemzeti Tankönyvtárában van lehetőség. (Molnár-Kovács, 2019) Online hozzáférés tehát (egyelöre) nem lehetséges a tankönyvi kötetek átfogó feltérképezéséhez, megismeréséhez, ugyanakkor a történeti tankönyvkutatások elömozdításának — és a források hosszútávú állagmegőrzének — egyik záloga a tankönyvek digitalizálási munkálatainak ösztönzése, az erre irányuló törekvések hatékony érvényesítése, valamint a digitalizált forrásdokumentumokhoz való online hozzáférés széleskörü biztosítása.

\section{Tankönyvszerzői iratanyagok, hagyatékok}

A tankönyvszerzői iratanyagok, illetve hagyatékok legfőbb lelöhelyei természetszerüleg a levéltárak, kézirattárak, így például Schultz Imre (tankönyvszerző, tanító, tanítóképző-intézeti igazgató) irathagyatéka a Pécsi Tudományegyetem Egyetemi Levéltár állományát gazdagítja (PTE EL XIV. 801. Schultz Imre irathagyatéka). A hazai levéltári iratanyagok, illetve források online adatbázisai ugyanakkor szintúgy hasznos kutatási platformot kínálnak. Kiemelkedik ezek közül a Hungaricana adatbázis, melyen keresztül - a Könyv-és Dokumentumtárban - a Levéltári iratok ${ }^{15}$ és a Levéltári kiadványok ${ }^{16}$ online is elérhetőek. A főbb online lelőhelyek közt tehát mindenekelőtt a Hungaricana közgyüjteményi portál ${ }^{17}$ jelentőségét hangsúlyozzuk, ugyanakkor a Magyar Nemzeti Levéltár adatbázisait ${ }^{18}$ is érdemes tüzetesebb vizsgálat alá vetni. (lásd még Molnár-Kovács, 2019)

\section{Iskolai értesitök}

A nevelés- és oktatástörténeti kutatásokban az iskolai értesítők kiemelkedő forrásértéke különösen iskolatörténeti és helytörténeti aspektusból ismeretes. A hazai iskolai értesítők történeti tankönyvkutatásokban betöltött szerepe azonban kevésbé ismert, azok autentikus elsődleges forrásként való érvényesülése a tankönyvkutatások során

15 Levéltári iratok - Hungaricana https://library.hungaricana.hu/hu/collection/leveltari_iratok/

16 Levéltári kiadványok - Hungaricana https://library.hungaricana.hu/hu/collection/magyarorszagi_leveltarak_kiadvanyai/

17 Hungaricana közgyüjteményi portál - https://library.hungaricana.hu/hu/

18 Magyar Nemzeti Levéltár - Adatbázisok - http://mnl.gov.hu/adatbazisok 
mindenekelőtt a tankönyvhasználat- és a tankönyvszerzői életútvizsgálat során érhetö tetten. (lásd Molnár-Kovács, 2019)

Az iskolai értesítők az Országos Pedagógiai Könyvtár és Múzeum $^{19}$ egyik különgyüjteményét alkotják, mely a teljesség igényével gyüjti annak példányait (lásd Gráberné Bösze, 2007). ${ }^{20} \mathrm{Az}$ értesítőkre alapozott kutatásokat elősegíti továbbá, hogy a Hungaricana adatbázison keresztül a Könyv- és Dokumentumtárban egyrészt az Iskolai értesitő $k$ digitalizált gyüjteménye, másrészt pedig ,A magyarországi iskolai értesitők bibliográfiájának" kötetei is elérhetőek. ${ }^{21}$

\section{Dualizmus korabeli tankönyvi (szak)irodalom}

A dualizmus korabeli pedagógiai szaklapok közül mindenekelött a Magyar Paedagogiát, mint az első hazai tudományos nevelésügyi folyóiratot említjük. A dualizmus idején az Értekezések (később Tanulmányok), a Hazai irodalom és a Vegyesek címü rovata is rendszeresen közölt tankönyvekkel kapcsolatos cikkeket. Az 1868-ban induló Néptanitók Lapjában, a Vallás- és Közoktatásügyi Minisztérium hivatalos orgánumában szintén jellemző volt a tankönyvekről szóló írások (cikkek, cikksorozatok) közreadása. A Néptanitók Lapja azonban más szempontból is külön figyelmet kíván, hiszen a Hivatalos Közlönnyel és a Magyarországi Rendeletek Tárával együtt a korszak tankönyvi rendeleteinek, valamint az engedélyezett tankönyvek jegyzékének főbb forráskiadványait jelentették. Szót kell ejtenünk továbbá az 1867-ben alapított Országos Középiskolai Tanáregylet folyóiratáról, az Országos Középiskolai Tanáregyesületi Közlönyröl, mely szintén rendszeresen jelentetett meg tankönyvi írásokat. (lásd Molnár-Kovács, 2019. 109-113. o.)

E folyóiratok föbb online lelöhelyét a korábbiakban már többször méltán hangsúlyozott Arcanum Digitális Tudománytár ${ }^{22}$ jelenti.

\section{8 utáni tankönyvi szakirodalom}

Ahogy valamennyi tudományos vizsgálódás során joggal várható, kellő figyelmet szükséges fordítanunk azokra a kutatási előzményekre, publikációkra, tendenciákra, melyekre napjainkban az 1867-1918

19 Országos Pedagógiai Könyvtár és Múzeum, Budapest - https://www.opkm.hu

20 Iskolai értesítők különgyüjteménye - OPKM https://www.opkm.hu/?lap=dok/dok\&dok_id=15

21 Iskolai értesítők - Hungaricana https://library.hungaricana.hu/hu/collection/iskolai_ertesitok

22 Arcanum Digitális Tudománytár - https://adtplus.arcanum.hu/hu/ 
közötti korszakot fókuszba állító tankönyvkutatások támaszkodhatnak, s melyekre építve a korszak tankönyveinek vizsgálata teljes bizonyossággal tovább strukturálható, fejleszthető. A kutatási előzmények teljességre törekvő összegyüjtése során lehetőségünk nyílik akarva-akaratlanul, de tulajdonképpen megkerülhetetlenül - a másodlagos források digitális hozzáférhetőségének feltérképezésére is.

A forráskiadványok közt számos folyóiratcikk sorakozik: a vizsgált szakirodalmi tételek közel 2/3-a könyvfejezet formájában vagy (szak)folyóiratban közzétett tanulmányként azonosítható (lásd Molnár-Kovács, 2019). A folyóiratok sorában megtaláljuk például a Magyar Pedagógiát ${ }^{23}$, az Educatiot ${ }^{24}$, a Könyv és Nevelést ${ }^{25}$, az Iskolakultúrá ${ }^{26}$, a Neveléstörténetet ${ }^{27}$, a Történelemtanítás ${ }^{28}$, melyek releváns cikkeihez való digitális hozzáférés meglehetősen széleskörü. A folyóiratcikkek esetében ezért alapvető tájékozódási kiindulópontot jelent a folyóiratok internetes honlapjainak felkeresése, továbbá az adatbázis-alapú keresés, melyek közül első körben az Elektronikus Periodika Archívum és Adatbázist ${ }^{29}$ ajánljuk. ${ }^{30}$

\section{Összegző gondolatok}

A nevelés- és müvelödéstörténeti források - így a történeti tankönyvkutatások során is elötérbe kerülő forrásanyagok — esetében egyre sürgetőbb igény mutatkozik a digitális világ nyújtotta elönyök érvényesítésére, tehát mind az elsődleges, mind pedig a másodlagos kútfőket tekintve a széleskörü elektronikus alapú hozzáférés lehetőségének megteremtésére.

A hazai tankönyvek - nemzetközi trendekhez is igazodó - digitalizálási folyamatának felgyorsítását különösképpen hangsúlyozni szükséges, hiszen a közgyüjtemények felkeresésének akadályoztatása esetén az aktív kutatói tevékenység ezáltal valóban fenntartható és

\footnotetext{
23 Magyar Pedagógia - http://www.magyarpedagogia.hu/

24 Educatio - http://www.hier.iif.hu/hu/index.php lásd még Educatio - AKJournals https://akjournals.com/view/journals/2063/2063-overview.xml

25 Könyv és Nevelés - https://folyoiratok.oh.gov.hu/konyv-es-neveles

26 Iskolakultúra - http://www.iskolakultura.hu/index.php/iskolakultura/

27 Neveléstörténet - http://www.kodolanyi.hu/nevelestortenet/ lásd még Polymatheia - http://www.polymatheia.hu

28 Történelemtanítás - Online történelemdidaktikai folyóirat https://www.folyoirat.tortenelemtanitas.hu/

29 Elektronikus Periodika Archívum és Adatbázis - http://epa.oszk.hu/

30 Lásd még például Magyar Nemzeti Digitális Archívum - https://mandadb.hu/
} 
tovább erősíthető, emellett a digitalizált dokumentumokra épített elemző vizsgálatok hatékonysága fokozható és tovább mélyíthető.

\section{Kérdések és válaszok}

1. Melyek azok a föbb online hazai adatbázisok, melyek a történeti tankönyvkutatások forrásaihoz való hozzáférés tekintetében meghatározóak?

Arcanum Digitális Tudománytár - https://adtplus.arcanum.hu/hu/ Hungaricana közgyüjteményi portál - https://library.hungaricana.hu/hu/

2. Soroljon fel néhány olyan, az elmúlt 10 évben megjelent könyvet, melyek a magyar tankönyvkutatások elsödleges és/vagy másodlagos forrásait helyezik az érdeklödés fókuszába!

Például:

- Molnár-Kovács Zsófia (2013): A tankönyvkutatás magyar bibliográfiája (2000-2010). Különös tekintettel a történelemtankönyvek vizsgálatára. A Pécsi Egyetemi Könyvtár kiadványai 11. Pécsi Tudományegyetem Egyetemi Könyvtár, Pécs - https://bit.ly/3rQJ2p0

- Molnár-Kovács Zsófia (2017): A tankönyvkutatások dualizmus kori forrásai. Tanulmányok és forrásgyüjtemény. Capillatus Kiadó, Pécs.

- Molnár-Kovács Zsófia (2019): A magyar tankönyvkutatások forrásdimenziói (1867-1918). Institutio Kiadó, Pécs.

3. Vázolja fel a magyar tankönyvkutatások forrásdimenzióinak (18671918) rendszerét!

Lásd a tanulmány 4. képét - A magyar tankönyvkutatások forrásdimenziói (1867-1918) (Forrás: Molnár-Kovács, 2019. 15. o.)

4. A tananyagban olvasottak és az értesitökben fellelt adatok alapján hogyan vélekedik arról, hogy milyen aspektusból játszanak meghatározó szerepet az iskolai értesitök a történeti tankönyvkutatásokban?

Nyissa meg a Hungaricana adatbázison keresztül az Iskolai értesítök digitalizált gyüjteményét (http://bit.ly/3d9S1hd), azon belül pedig az Iskolai értesitök helységnév szerint címü felületet! Válasszon ki néhány intézményt, s lehetőség szerint nézzen át 2-3 (vagy tetszés szerint akár több) iskolai értesítöt, s keressen bennük tankönyvekre vonatkozó adatokat, információkat! 
A hazai iskolai értesítőkben adott intézményre, adott évfolyamra (osztályra) és adott tanévre vonatkozóan tankönyvhasználati adatokat találunk, melyek vagy az adott tanévben elvégzett iskolai tananyag részeként vagy külön tankönyvjegyzék formájában kerültek feltüntetésre. Emellett pedig a tankönyvszerzők életút-vizsgálata kapcsán az iskolai értesítőkben rögzített tények és adatok hozzájárulnak a tankönyvszerzők életének és munkásságának részletekbe menő megismeréséhez.

5. Melyek azok pedagógiai szaklapok, melyek a dualizmus korában, illetve 1918 után (a dualizmus korára vonatkozóan) rendszeresen közöltek/közölnek tankönyvekkel kapcsolatos cikkeket, tankönyvi írásokat?

Emeljen ki néhány példát a folyóiratok közül és jelölje meg ezek főbb online hozzáférési lehetőségeit!

Dualizmus korabeli például:

- Magyar Paedagogia,

- Néptanítók Lapja,

- Hivatalos Közlöny,

- Országos Középiskolai Tanáregyesületi Közlöny

1918 utáni például:

- Magyar Pedagógia,

- Educatio,

- Könyv és Nevelés,

- Iskolakultúra,

- Neveléstörténet,

- Történelemtanítás

A dualizmus kori pedagógiai szaklapok föbb online lelőhelye az Arcanum Digitális Tudománytár. ${ }^{31}$ Az 1918 utáni folyóiratcikkek esetében pedig első körben a folyóiratok internetes honlapjainak felkeresése javasolt, továbbá az adatbázisok közül az Elektronikus Periodika Archívum és Adatbázis ${ }^{32}$ meghatározó.

31 Arcanum Digitális Tudománytár - https://adtplus.arcanum.hu/hu/

32 Elektronikus Periodika Archívum és Adatbázis - http://epa.oszk.hu/ 


\section{Irodalom}

A népiskolai olvasó-, tan- és vezérkönyvek kidolgozása tárgyában közoktatási m. kir. miniszter ur ö excellentiája által összehivott bizottság értekezleteinek jegyzőkönyve, 1868. aug. 3-ától 11-ig. Néptanitók Lapja, 1868a. 41. sz. 641-646.

A népiskolai olvasó-, tan- és vezérkönyvek kidolgozása tárgyában közoktatási m. kir. miniszter ur ö excellentiája által összehivott bizottság értekezleteinek jegyzőkönyve, 1868. aug. 3-ától 11-ig. Néptanitók Lapja, 1868b. 42. sz. 657-662.

A népiskolai olvasó-, tan- és vezérkönyvek kidolgozása tárgyában közoktatási m. kir. minister ur ő excellentiája által összehivott bizottság értekezleteinek jegyzőkönyve, 1868. aug. 3-ától 11-ig. Budapesti Közlöny, 1868c. 272. sz. 2576-2577., 2579.

A népiskolai olvasó-, tan- és vezérkönyvek kidolgozása tárgyában közoktatási m. kir. minister ur ő excellentiája által összehivott bizottság értekezleteinek jegyzőkönyve, 1868. aug. 3-ától 11-ig. Budapesti Közlöny, 1868d. 273. sz. 2592-2593., 2595-2596.

Dölle Ödön (1871): A nevelészet története. Tanitók és tanitójelöltek számára. Lauffer Vilmos tulajdona, Pest.

Gráberné Bősze Klára (2007): A magyarországi iskolai értesítők/évkönyvek évszázadai, és bibliográfiai feltárásuk. Könyv és Nevelés, IX. 1. sz. 7785. - https://epa.oszk.hu/01200/01245/00033/gbk_0701.htm

Lévay Ferencz, Morlin Emil és Szuppán Vilmos (1893, szerk.): A magyarországi népoktatásügy, kereskedelmi és ipari szakoktatás szervezete és közigazgatása. A kisdedóvásra, népoktatási tanintézetekre, (elemi és felsö népiskolákra, polgári iskolákra, tanitóképzö intézetekre), felsőbb leányiskolákra, kereskedelmi tanintézetekre és a vallás- és közoktatásügyi ministerium hatáskörébe tartozó ipariskolákra vonatkozó összes törvények, szabályrendeletek, utasitások, rendeletek és döntvények gyüjteménye. (I. kötet.) Kisdedóvás és népoktatás (elemi, felső nép- és polgári iskolák). Eggenberger-féle Könyvkereskedés, Budapest

Márhoffer Nikolett (2013): Fontos bibliográfia született a tankönyvkutatók számára. Gondolatok Molnár-Kovács Zsófia: A tankönyvkutatás magyar bibliográfiája (2000-2010) c. kötetéről. Történelemtanítás - Online Történelemdidaktikai folyóirat, (XLVIII.) Új folyam IV. 3-4. sz. https://bit.ly/3rR9A9G

Molnár-Kovács Zsófia (2013a): A tankönyvkutatás 21. századi magyar szakirodalmáról. Történelemtanítás - Online Történelemdidaktikai folyóirat, (XLVIII.) Új folyam IV. 3-4. sz. - https://bit.ly/3b6Bbgk

Molnár-Kovács Zsófia (2013b): A tankönyvkutatás magyar bibliográfiája (2000-2010). Különös tekintettel a történelemtankönyvek vizsgálatára. A Pécsi Egyetemi Könyvtár kiadványai 11. Pécsi Tudományegyetem Egyetemi Könyvtár, Pécs. https://bit.ly/3rQJ2p0

Molnár-Kovács Zsófia (2017): A tankönyvkutatások dualizmus kori forrásai. Tanulmányok és forrásgyüjtemény. Capillatus Kiadó, Pécs. 
Molnár-Kovács Zsófia (2019): A magyar tankönyvkutatások forrásdimenziói (1867-1918). Institutio Kiadó, Pécs

Morlin Emil és Szuppán Vilmos (1898, szerk.): A magyarországi népoktatásügy, kereskedelmi és ipari szakoktatás szervezete és közigazgatása. A kisdedóvásra, népoktatási tanintézetekre (elemi és felső népiskolákra, polgári iskolákra, tanitóképzö intézetekre), felsőbb leányiskolákra, kereskedelmi tanintézetekre és a vallás- és közoktatásügyi ministerium hatáskörébe tartozó ipariskolákra vonatkozó összes törvények, szabályrendeletek, utasitások, rendeletek és döntvények gyüjteménye. (II. kötet.) Tanitóképzés, felsőbb leányiskolák, szakoktatás stb. Eggenberger-féle Könyvkereskedés, Budapest

Vajda Barnabás (2020): Történelemdidaktika és történelemtankönyvkutatás. Selye János Egyetem Tanárképző Kar, Komárom

https://bit.ly/2LLYyDh

\section{Levéltári forrás}

Pécsi Tudományegyetem Egyetemi Levéltár (PTE EL) XIV. 801. Schultz Imre irathagyatéka

\section{Internetes források}

- Arcanum Digitális Tudománytár https://adtplus.arcanum.hu/hu/

- Arcanum Digitális Tudománytár - Ismertető http://www.arcanum.hu/hu/adt/

- Digitália - Pécsi Tudományegyetem https://digitalia.lib.pte.hu/

- Digitalizált Törvényhozási Tudástár - Gyüjteményismertetők https://dt.ogyk.hu/hu/

- Digitalizált Törvényhozási Tudástár - Magyarországi Rendeletek Tára - https://bit.ly/3jMCMff

- Educatio http://www.hier.iif.hu/hu/index.php

- Educatio - AKJournals https://akjournals.com/view/journals/2063/2063-overview.xml

- Elektronikus Periodika Archívum és Adatbázis http://epa.oszk.hu/

- Georg-Eckert-Institut - Leibniz-Institut für internationale Schulbuchforschung, Braunschweig http://www.gei.de/home.html 
- Hungaricana közgyüjteményi portál https://library.hungaricana.hu/hu/

- Iskolai értesítők - Hungaricana https://library.hungaricana.hu/hu/collection/iskolai_ertesitok

- Iskolai értesítők különgyüjteménye - OPKM https://www.opkm.hu/?lap=dok/dok\&dok_id=15

- Iskolakultúra http://www.iskolakultura.hu/index.php/iskolakultura/

- Könyv és Nevelés https://folyoiratok.oh.gov.hu/konyv-es-neveles

- Levéltári iratok - Hungaricana https://library.hungaricana.hu/hu/collection/leveltari_iratok/

- Levéltári kiadványok - Hungaricana http://bit.ly/377OD2o

- Magyar Nemzeti Digitális Archívum https://mandadb.hu/

- Magyar Nemzeti Levéltár - Adatbázisok http://mnl.gov.hu/adatbazisok

- Magyar Pedagógia http://www.magyarpedagogia.hu/

- Magyarországi Rendeletek Tára 1867-1945 https://library.hungaricana.hu/hu/collection/ogyk_rendeletek_tara/

- Neveléstörténet http://www.kodolanyi.hu/nevelestortenet/

- Országos Pedagógiai Könyvtár és Múzeum, Budapest https://www.opkm.hu/

- Polymatheia http://www.polymatheia.hu/

- Tantervek - Digitália - Pécsi Tudományegyetem https://bit.ly/3t77gwT

- Történelemtanítás - Online történelemdidaktikai folyóirat https://www.folyoirat.tortenelemtanitas.hu/ 